\title{
Implementing standard of competition development in markets of educational services and socially important services assessed by entrepreneurs of large city
}

\author{
Alexandr Kokovikhin \\ Ural State University of Economics, \\ 620014, Ekaterinburg, Russia \\ kau@usue.ru
}

\begin{abstract}
The article presents the results of studying satisfaction of customers and small and medium-sized businesses with the competitive environment in the markets of Yekaterinburg. Data on satisfaction with the competitive environment in 2016 were obtained in the survey of more than 500 respondents in the municipality of Ekaterinburg. It was done as part of research for the Ministry of Investments and Development of Sverdlovsk Region. The scientific research work was "Monitoring the presence (absence) of administrative barriers and assessing the state of the competitive environment by subjects of entrepreneurial activity and monitoring customer satisfaction with the quality of goods, works and services on commodity markets in Sverdlovsk region and the state of price competition in Sverdlovsk region. The results of the research made it possible to rank the institutional barriers to the development of competition and, on this basis, to identify the main strategies for state authorities and local self-government bodies to improve the institutional environment for the activities of small and medium-sized businesses.
\end{abstract}

Keywords - new public management; standard of competition; markets; Russian Federation; Ekaterinburg.

\section{INTRODUCTION}

Creating a favourable competitive environment is an integral part of sustainable socio-economic development of the territory and the key to attracting investment in the city's economy. The government of Sverdlovsk region pays special attention to systematic work in this direction. The standard of competition development in the Russian Federation, launched in Sverdlovsk region in 2015, has become a solid Foundation for improving the competitive environment.

The main target of implementing the Standard are consumers who are interested in the variety of supply on socially important markets and the business entities providing it. The actual problem is methodological provision aimed at monitoring the level of satisfaction with the state and development of competition in the goods and services markets.

The purpose of the study, which became the basis of this

Researches was made for Regional Ministry of Investment and Development (Sverdlovsk oblast) (state contract No. 04-2017-14). article, is understanding how the actions in the framework of the Standard of competition are being taken.

Achieving the goal involves solving the following problems: developing appropriate methodological tools, including the content of questionnaires; defining regulations in the use of tools to collect information; forming evaluation algorithms that allow one to judge the effectiveness of the Standard of competition implementation, identifying the main activities of government bodies and local authorities to improve the institutional environment for small and mediumsize business activities.

\section{THEORETICAL FRAMEWORK OF RESEARCH}

A paradigm shift in public administration, which took place in the Anglo-Saxon management in the 1990s and was reflected in the 2003 Administrative reform in the Russian Federation, is associated with the transition from public administration to the concept of new public management, according to which management techniques developed by corporations are transferred to the public sector [1].

In the researches devoted to the questions of state (regional) governance, institutional analysis, including administrative barriers is the starting point of the public policy formation [2]. Currently, institutional and administrative barriers as the most important factors of control are found in innovation policy, industrial policy, investment policy [3].

The role of entrepreneurship in shaping the spatial distribution of economic activity across the country was first presented in the work of A. Marshall 1890 [4]. Entrepreneurs are responsible not only for the creation of new firms, but also for their technological lead and success, as well as creating new jobs [5]. Thus, entrepreneurs are the driving force of economic growth and they form inequalities in the development of certain territories within a country [6]. It is not surprising that at all levels of government, significant attention is paid to supporting entrepreneurs and creating a number of institutions aimed at the implementation of this goal [7]. For example, for these purposes, in 1953 in the United States, they 
created the Small Business Administration (SBA) agency [8], to help Americans "start, build and grow the business". In the UK, this is being implemented by the Department for Business, Innovation and Skills (BIS) [9].

In the Russian Federation at the Federal level, this is done by the Department of small and medium-size entrepreneurship and competition of the Ministry of economic development of the Russian Federation, which carries out activities associated with the following main directions [10]: the legal regulation of small and medium-size enterprises, the programme of providing support to small and medium-size enterprises, crediting of small and medium-size enterprises, international cooperation in the sphere of small and medium-size business.

Practical work on the formation of competitive environment is concentrated at the regional level of government, due to localizations of most markets within a certain area. To unify and improve the controllability of this process, the Russian Federation government act of September 5, 2015-No. 1738-r approved the Standard of competition development in the Russian Federation subjects. The aims of the Standard implementation are [11]:

a) establishing a systematic and uniform approach to the activities of executive authorities of the Russian Federation constituent subjects, local self-governing bodies and territorial bodies of the Federal Executive to create conditions for developing competition between economic subjects in the sectors of economy;

b) promoting the formation of a transparent system of executive authorities in the constituent subjects of the Russian Federation taking efficient and effective measures for competition development in the interests of consumers of goods, work and services, including business entities, citizens and the society;

c) identifying the potential for the economic development of the Russian Federation, including scientific- technological and human potential;

d) creating incentives and promoting conditions for the development, support and protection of small and mediumsize enterprises, as well as heling to eliminate administrative barriers.

Indicators of implementing the Standard at the regional level are included in the List of efficiency evaluation indicators of top-level officials (heads of higher executive bodies of the government ) of the Russian Federation subjects on creating favourable conditions for business activity (till 2018). It was approved by the Russian Federation Government decree of 10 April 2014 No. 570-R [12].

According to this List, monitoring and assessment are given to the number of implemented components of the Standard for competition development in the subjects of the Russian Federation. The specific aspects of the monitoring are presented in the work [13].

\section{METHODOLOGY}

The monitoring methodology, which suggests a sequential decomposition of the overall task of competition development, is presented in table 1 . The data on the state and development of competitive environment in the priority and socially important markets of Sverdlovsk region were received in the framework of the current monitoring conducted by the department executive bodies of Sverdlovsk region, as well as based on the results of polls and surveys organized by business associations and industrial unions.

TABLE I. STRUCTURED EVALUATION OF COMPETITIVE ENVIRONMENT ON THE MARKETS OF SVERDLOVSK REGION DONE BY REPRESENTATIVES OF ORGANIZATIONS (PART 1)

\begin{tabular}{|c|c|c|}
\hline \multirow{7}{*}{ 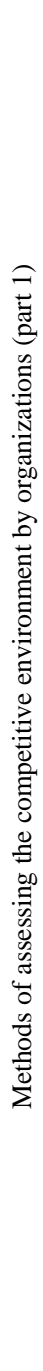 } & \multirow{3}{*}{ 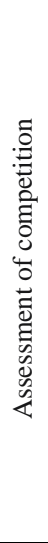 } & $\begin{array}{l}\text { 1. Characteristics of the competitive conditions in the } \\
\text { market: } \\
\text { - No real competition } \\
\text { - Middle level of competition } \\
\text { - Moderate competition }\end{array}$ \\
\hline & & $\begin{array}{l}\text { 2. Assessment of the quality of official information } \\
\text { about competitive environment in the markets of goods } \\
\text { and services of Sverdlovsk region: } \\
\text { - Level of access } \\
\text { - The level of clarity } \\
\text { - Convenience of getting }\end{array}$ \\
\hline & & $\begin{array}{l}\text { 3. Estimating the number of suppliers of the primary } \\
\text { product you purchase: } \\
\text { - Only } 1 \text { supplier / Unsatisfactory } \\
\text { - 2-3 suppliers / Rather poor } \\
\text { - } 4 \text { and more suppliers/ rather satisfactory } \\
\text { - A large number of suppliers / Satisfactory }\end{array}$ \\
\hline & 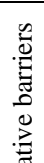 & $\begin{array}{l}\text { 1. The ranking of administrative barriers in the context } \\
\text { of: } \\
\text { - procedures associated with starting a business } \\
\text { - procedures associated with the business location } \\
\text { - aspects related to business activities }\end{array}$ \\
\hline & 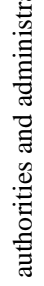 & $\begin{array}{l}\text { 2. The change in the level of administrative barriers } \\
\text { over the last } 3 \text { years in the market: } \\
\text { - Completely eliminated } \\
\text { - It has become easier than before } \\
\text { - The level and number of administrative barriers have } \\
\text { not changed } \\
\text { - It has become harder than before } \\
\text { - Administrative barriers have appeared } \\
\text { - Administrative barriers have not existed previously }\end{array}$ \\
\hline & $\because$ & 3. Control events and the activities of the authorities \\
\hline & 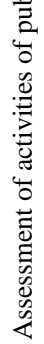 & $\begin{array}{l}\text { 4. Characteristics of the authorities activities in the } \\
\text { market: } \\
\text { - Government authorities help the business } \\
\text { - Government authorities do nothing } \\
\text { - The authorities only interfere with the business } \\
\text { - In some matters authorities help, in others they y } \\
\text { hinder }\end{array}$ \\
\hline
\end{tabular}


TABLE II. STRUCTURED EVALUATION OF COMPETITIVE ENVIRONMENT ON THE MARKETS OF SVERDLOVSK REGION DONE BY REPRESENTATIVES OF ORGANIZATIONS (PART 2)

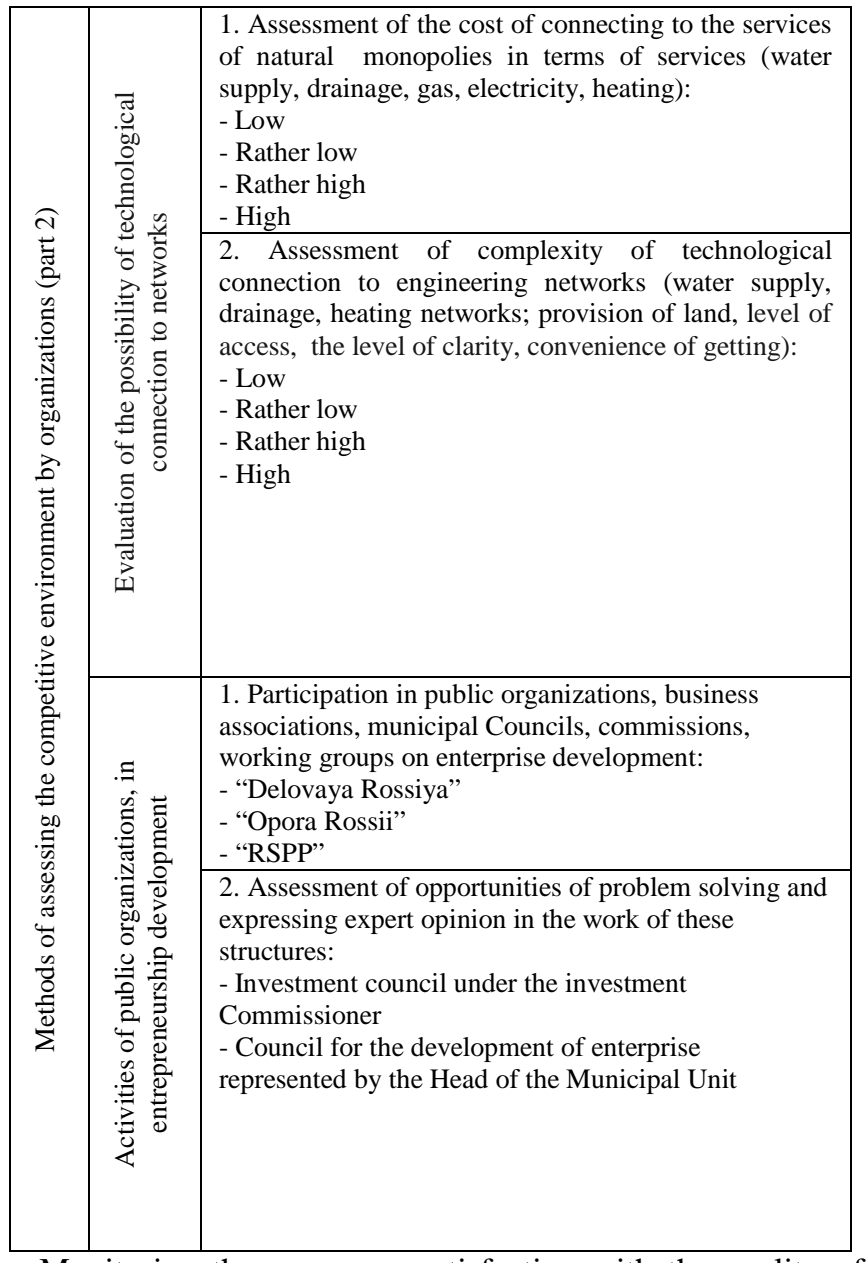

Monitoring the consumer satisfaction with the quality of goods, works and services, including information about the complaints from consumers and business entities, addressed to the supervisory authorities, is systematically carried out by the government executive bodies of Sverdlovsk region, which perform control and supervision functions.

\section{THE RESULT OF RESEARCH}

The evaluation of main parameters of development of socially important markets in Sverdlovsk region is presented in figures 1 and table 2 .

Most representatives of organizations in socially important markets of Sverdlovsk region are sure that competition is moderate and requires measures to increase the competitiveness of products / works / services, such as lower prices, higher quality, development of related services, etc. [14] Exceptions are the markets for the services of psychological and pedagogical support for children with disabilities and services for children's recreation and rehabilitation [15]. Evaluation of the supplier base gives preferential assessment of "2-3 suppliers as rather unsatisfactory."
The main factors that restrict competition development in socially important markets of Sverdlovsk region are the following:

- at the stage of starting a business - business registration;

- at the stage of placing a business - the acquisition of buildings, premises;

- at the stage of business activity - tax burden;

In addition to these barriers, respondents note difficulties in obtaining land and connecting to engineering networks (Tables 3, 4, 5).

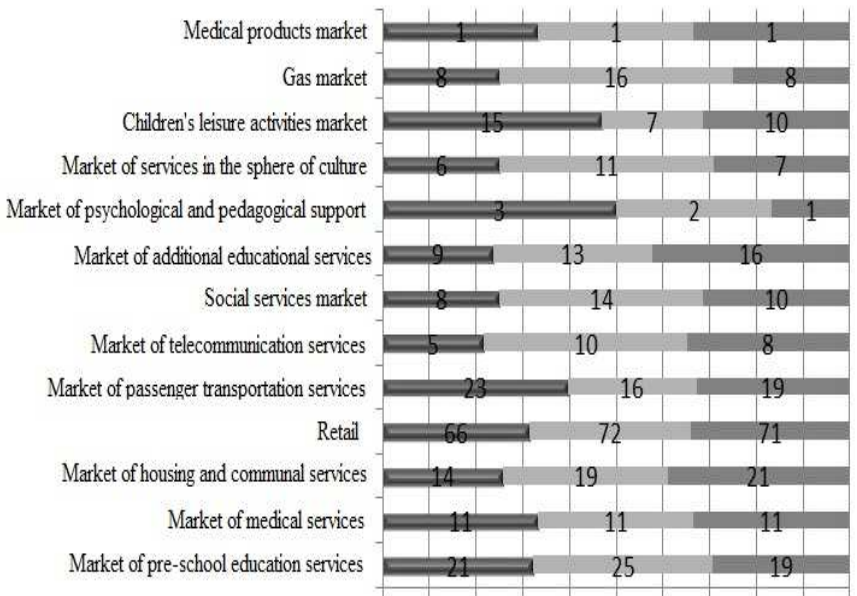

$0 \% 10 \% 20 \% 30 \%$ 40\% 50\% 60\% 70\% 80\% 90\% $100 \%$
No real competition
Intense competition

Moderate competition

Fig. 1. Characteristics of competitive conditions in the markets

TABLE III. ENTREPRENEURS' ESTIMATION OF ADMINISTRATIVE BARRIERS IN THE MARKETS BY THE END OF 2016 (AT THE STAGE OF STARTING A BUSINESS)

\begin{tabular}{|c|c|c|}
\hline \multirow[t]{2}{*}{$\begin{array}{l}\text { Socially important markets of } \\
\text { Sverdlovsk region }\end{array}$} & \multicolumn{2}{|c|}{$\begin{array}{l}\text { Procedures related to starting a } \\
\text { business }\end{array}$} \\
\hline & $\begin{array}{l}\text { Business } \\
\text { registration }\end{array}$ & Licensing \\
\hline $\begin{array}{c}\text { 1.Market of pre-school education } \\
\text { services }\end{array}$ & 35 & 29 \\
\hline 2.Market of medical services & 20 & 12 \\
\hline $\begin{array}{l}\text { 3.Market of housing and communal } \\
\text { services }\end{array}$ & 54 & 0 \\
\hline 4. Retail trade & 109 & 100 \\
\hline $\begin{array}{l}\text { 5.Market of passenger } \\
\text { transportation by land }\end{array}$ & 26 & 0 \\
\hline 6.Communication services market & 9 & 0 \\
\hline
\end{tabular}


TABLE IV. ENTREPRENEURS' ESTIMATION OF ADMINISTRATIVE BARRIERS IN THE MARKETS BY THE END OF 2016 (AT THE STAGE OF PLACING A BUSINESS)

\begin{tabular}{|c|c|c|c|c|c|c|}
\hline \multirow{2}{*}{$\begin{array}{l}\text { Socially important markets } \\
\text { of Sverdlovsk region }\end{array}$} & \multicolumn{6}{|c|}{ Procedures related to placing a business } \\
\hline & 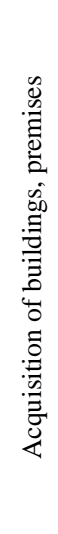 & 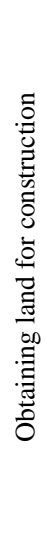 & 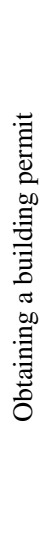 & 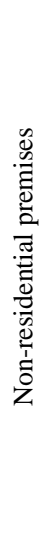 & 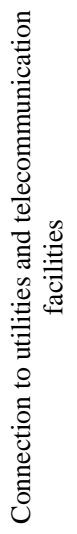 & 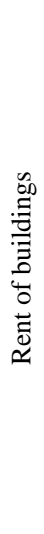 \\
\hline $\begin{array}{l}\text { 1.Market of pre-school } \\
\text { education services }\end{array}$ & 9 & 9 & 6 & 21 & 13 & 7 \\
\hline $\begin{array}{l}\text { 2.Market of medical } \\
\text { services }\end{array}$ & 5 & 6 & 5 & 8 & 3 & 0 \\
\hline $\begin{array}{l}\text { 3.Market of housing and } \\
\text { communal services }\end{array}$ & 12 & 6 & 12 & 12 & 7 & 5 \\
\hline 4. Retail trade & 31 & 31 & 44 & 28 & 75 & 0 \\
\hline $\begin{array}{l}\text { 5.Market of passenger } \\
\text { transportation by land }\end{array}$ & 14 & 8 & 6 & 15 & 11 & 0 \\
\hline $\begin{array}{l}\text { 6.Communication services } \\
\text { market }\end{array}$ & 4 & 4 & 3 & 3 & 3 & 0 \\
\hline 7.Market of social services & 7 & 3 & 3 & 11 & 6 & 0 \\
\hline $\begin{array}{c}\text { 8.Market of additional } \\
\text { education services for } \\
\text { children }\end{array}$ & 5 & 5 & 7 & 4 & 8 & 0 \\
\hline $\begin{array}{l}\text { 9.Market of psychological } \\
\text { and pedagogical support } \\
\text { services for children with } \\
\text { disabilities }\end{array}$ & 1 & 1 & 0 & 1 & 3 & 0 \\
\hline $\begin{array}{l}\text { 10. Market of services in } \\
\text { the sphere of culture }\end{array}$ & 6 & 3 & 1 & 3 & 7 & 0 \\
\hline $\begin{array}{l}\text { 11. Market of children's } \\
\text { recreation and } \\
\text { rehabilitation services }\end{array}$ & 5 & 5 & 8 & 2 & 4 & 0 \\
\hline 12. Gas market & 8 & 5 & 8 & 1 & 2 & 0 \\
\hline $\begin{array}{l}\text { 13. Market of medical } \\
\text { products }\end{array}$ & 1 & 2 & 0 & 0 & 0 & 0 \\
\hline
\end{tabular}

TABLE V. TABLE 3. ENTREPRENEURS' ESTIMATION OF ADMINISTRATIVE BARRIERS IN THE MARKETS BY THE END OF 2016 (AT THE STAGE OF BUSINESS ACTIVITY)

\begin{tabular}{|c|c|c|c|c|c|c|c|}
\hline \multirow{2}{*}{$\begin{array}{l}\text { Socially important } \\
\text { markets of Sverdlovsk } \\
\text { region }\end{array}$} & \multicolumn{7}{|c|}{ Aspects related to business activities } \\
\hline & 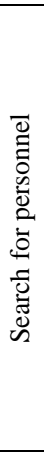 & 岕 & 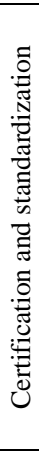 & 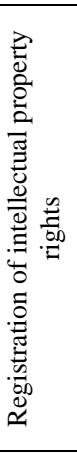 & 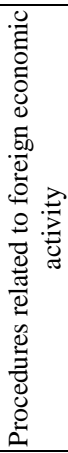 & 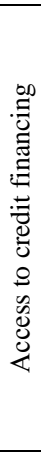 & 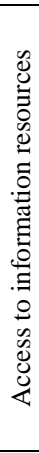 \\
\hline $\begin{array}{l}\text { 1.Market of pre- } \\
\text { school education } \\
\text { services }\end{array}$ & 7 & 11 & 4 & 8 & 8 & 6 & 12 \\
\hline $\begin{array}{l}\text { 2.Market of medical } \\
\text { services }\end{array}$ & 4 & 3 & 5 & 9 & 3 & 0 & 1 \\
\hline $\begin{array}{l}\text { 3.Market of housing } \\
\text { and communal } \\
\text { services }\end{array}$ & 9 & 10 & 6 & 10 & 7 & 5 & 6 \\
\hline 4. Retail trade & 28 & 28 & 19 & 31 & 27 & 31 & 26 \\
\hline $\begin{array}{l}\text { 5.Market of passenger } \\
\text { transportation by land }\end{array}$ & 4 & 9 & 6 & 13 & 6 & 9 & 7 \\
\hline $\begin{array}{l}\text { 6.Communication } \\
\text { services market }\end{array}$ & 1 & 5 & 3 & 4 & 2 & 5 & 0 \\
\hline $\begin{array}{l}\text { 7.Market of social } \\
\text { services }\end{array}$ & 5 & 6 & 2 & 2 & 8 & 2 & 4 \\
\hline $\begin{array}{l}\text { 8.Market of additional } \\
\text { education services for } \\
\text { children }\end{array}$ & 5 & 11 & 3 & 4 & 5 & 1 & 7 \\
\hline $\begin{array}{l}\text { 9.Market of } \\
\text { psychological and } \\
\text { pedagogical support } \\
\text { services for children } \\
\text { with disabilities }\end{array}$ & 1 & 0 & 1 & 0 & 2 & 1 & 1 \\
\hline $\begin{array}{l}\text { 10. Market of services } \\
\text { in the sphere of } \\
\text { culture }\end{array}$ & 4 & 4 & 6 & 2 & 1 & 3 & 1 \\
\hline $\begin{array}{c}\text { 11. Market of } \\
\text { children's recreation } \\
\text { and rehabilitation } \\
\text { services }\end{array}$ & 4 & 5 & 6 & 2 & 1 & 8 & 1 \\
\hline 12. Gas market & 5 & 2 & 4 & 4 & 3 & 5 & 7 \\
\hline $\begin{array}{l}\text { 13. Market of medical } \\
\text { products }\end{array}$ & 1 & 0 & 1 & 0 & 0 & 0 & 1 \\
\hline
\end{tabular}




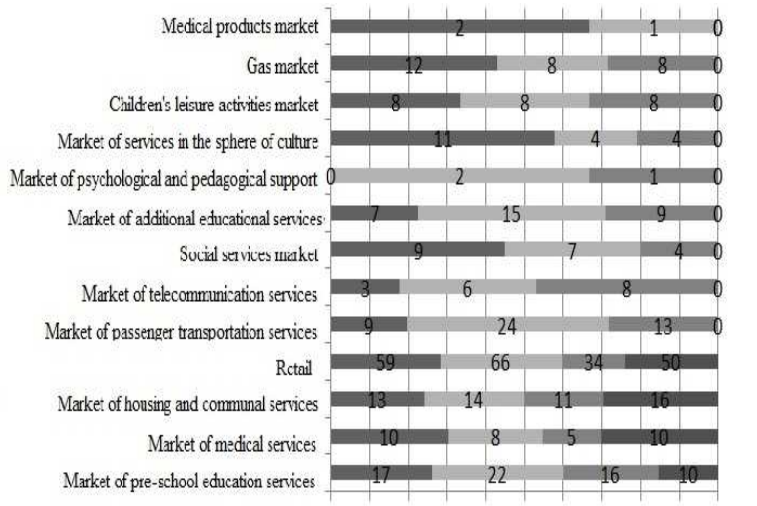

$0 \% 10 \% 20 \% 30 \%$ 40\% 50\% 60\% 70\% 80\% 90\% $100 \%$

$$
\begin{aligned}
& \text { - One supplier / unsatisfactory } \\
& \text { w } 2-3 \text { suppliers / rather unsatisfactory } \\
& \text { - } 4 \text { or more suppliers / rather satisfactory } \\
& \text { - Multiple suppliers / satisfacrory }
\end{aligned}
$$

Fig. 2. Characteristics of the supplier base development

\section{CONCLUSION}

The current system problems aimed at promotion of the development of competition in Ekaterinburg area are the following:

- organizing training events for local government authorities on issues of promoting competition;

considering complaints of consumers and business entities related to competition promotion, including those received through the official website;

monitoring the activities of natural monopoly entities in Ekaterinburg area and developing mechanisms for further public control over the activities of natural monopoly entities;

- introducing and (or) using the mechanism of technological and price audit of investment projects of natural monopoly entities;

One of the important tasks is to improve further cooperation with the Office of the Federal Antimonopoly service, including:

- the formation of more complete data on the competitive environment in the region, as well as assessing consumer satisfaction with the quality of goods, works, services and the state of price competition in the markets;

- organizing the joint work in drafting legal acts as well as other documents and information, prepared to stimulate competition in the region through the Antimonopoly legislation;

- more active participation in correcting (if necessary) the adopted "road map" because the participation in forming "the road map" was minimal;

- competition advocacy;

- more active interaction with territorial bodies of Federal Executive authorities, public associations in the field of regulating activities of natural monopolies and control over activities of natural monopoly entities.

\section{References}

[1] J. Martinez, D. Osborne, T.Gaebler, Reinventing Government: How the Entrepreneurial Spirit Is Transforming the Public Sector., Manning N.
The Legacy of the New Public Management in Developing Countries Inter. Rev. Admin. Sci, № 67, 2001.

[2] N. Manning, The legacy of the New Public Management in developing countries. International Review of Administrative Sciences, 67(2), pp. 297-312, 2001.

[3] A. Chepurenko, Theory of Entrepreneurship: new results and prospects (Research papers). Moscow, Higher School of Economics, 2012.

[4] O. S. Belokrylova, I.V. Berezhnoy, V.V. Volchik the Evolution of institutional constraints in the economy, Rostov n/D: Izd-vo Growth. University press, 2003, 285 p.

[5] V.M. Komarov, V.A. Kotsyubinsky, P.N. Pavlov, T.A. Sutyrina, Institutional barriers innovative development of the Russian economy. M.: Publishing house of the Ranepa, 2013.

[6] G. Faggio, O. Silva, Self-employment and entrepreneurship in urban and rural labour markets. Journal of Urban Economics, 84, pp. 67-85, 2014.

[7] R. Roger, Stough Entrepreneurship and Regional Economic Development: Some reflections Journal of Regional Research Investigaciones Regionales, Volume 36, Special Issue 2016 `Journal of Regional Research Investigaciones Regionales.

[8] R. R. Stough, Entrepreneurship and regional economic development: some reflections. Investigaciones Regionales, 36, p. 129, 2016.

[9] A. Chepurenko, Small entrepreneurship and entrepreneurial activity of population in Russia in the context of the economic transformation. Historical Social Research/Historische Sozialforschung, pp. 301-319, 2010.

[10] Small Business Administration. (n.d.). Retrieved April 8, 2017, from https://www.sba.gov/ Small Business Administration (SBA) agency https://www.sba.gov/

[11] Department for Business, Innovation \& Skills - GOV.UK. (n.d.). Retrieved April 8, 2017, from https://www.gov.uk/government/organisations/department-for-businessinnovation-skills

[12] The Department of development of small and medium enterprises and competition

http://economy.gov.ru/minec/activity/sections/smallBusiness/

[13] The decree of the RF Government of 5 September 2015 No. 1738-R On approval of the Standard of competition development in the Russian Federation

http://government.ru/media/files/EPhsiaffQIT8bK1Eov94GawSO179Hx FI.pdf

[14] M.M. Perova, E.O. Bryazgina, V.V. Zhurba, Introduction of the Competition Development Standard in federal subjects of the Russian Federation as the Key Aspect of Social and Economic Development of Territories. Journal of Economics, Entrepreneurship and Law, 6(1), pp. 9-24, 2016. https://doi.org/10.18334/epp.6.1.35181

[15] A. Kokovikhin, N. Sharapova, I. Borisov, National system of certification of worker's competence and qualification as the institute of labour market. in 10th international days of statistics and economics (pp. 871-881). Univ Econ, Dept Stat \& Probabil; Univ Econ, Dept Microecon; Tech Univ Kosice, Fac Econ; Ton Duc Thang Univ, 2016.

A. Kokovikhin, E. Ogorodnikova, D. Williams, A. Plakhin, Institutional Factors in the Evaluation by the Entrepreneur of Municipality Investment Climate. Economy of region, 1(1), pp. 80-92, 2017. 